\title{
The role played by UNB in wood products innovation in Atlantic Canada
}

\author{
by Ying H. Chui ${ }^{1,2}$, Meng Gong ${ }^{1,3}$, Shaun Price ${ }^{1,4}$ and Felisa Chan ${ }^{1,3}$
}

\begin{abstract}
This paper provides an overview of the historical development of wood science instruction and research at the Faculty of Forestry and Environmental Management, University of New Brunswick, and the role played by the Wood Science and Technology Centre in enhancing the level of innovation in the wood industry in Atlantic Canada. A review of some of the wood product innovation needs for Atlantic Canada is also given.
\end{abstract}

Key words: wood product innovation, wood science education, lumber scanning, wood modification, structural wood products, reconstituted wood products, wood durability, wood chemical products

\section{RÉSUMÉ}

Cet article présente un survol de l'historique du développement de la formation et de la recherche en sciences du bois à l'Université du Nouveau-Brunswick, ainsi que du rôle joué par le Centre des sciences et technologies du bois dans laccroissement du niveau d'innovation dans l'industrie du bois dans la Région de l'Atlantique au Canada. Une revue de certains des besoins en matière d'innovation des produits de bois pour la Région Atlantique au Canada est également présentée.

Mots clés : innovation des produits de bois, formation en sciences du bois, numérisation par balayage du bois, modification du bois, produits de bois structural, produits de bois reconstitué, durabilité du bois, produits chimiques tirés du bois.

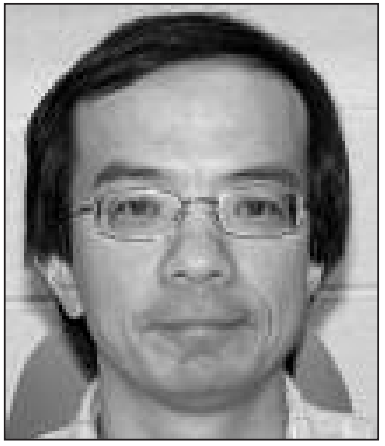

Ying H. Chui

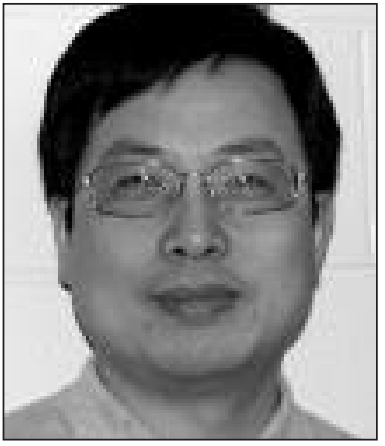

Meng Gong

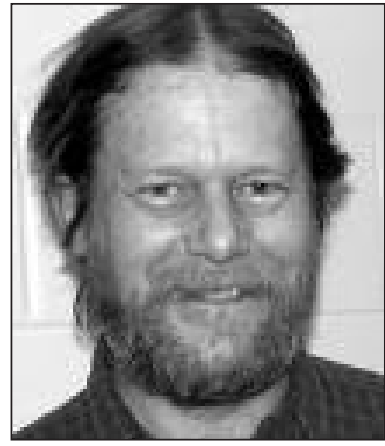

Shaun Price

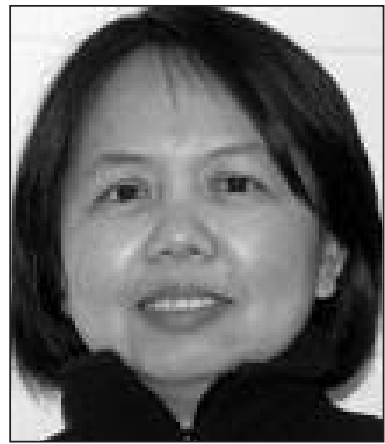

Felisa Chan
Historical Background of Wood Science and Technology Instruction and Research at UNB

The wood products industry is a major contributor to the economy of Atlantic Canada. In 2006 wood products shipments in the region were valued at $\$ 1.88$ billion. The industry supported about 260 establishments, and was responsible for about 21000 direct and indirect jobs in the region. The Faculty of Forestry and Environmental Management (formerly Faculty of Forestry) at the University of New Brunswick (UNB) has played a major role in both training of wood science and technology graduates to serve the needs of the industry, and assisting with the innovation needs of the industry since the 1960s.
The first serious offering of wood science and technology curriculum at UNB started in the early1970s with introduction of the Wood Science Option for students in the then Faculty of Forestry. This Option allowed undergraduate students to specialize in wood and wood products. Along with an increase in undergraduate teaching in wood science, research activities in that discipline were initiated by the two wood science faculty members, the late Dr. Leslie Sebastian and Dr. Marc Schneider. Some distinguished research work was conducted from the late 1970s into the 1980s by Dr. Sebastian on flow of fluid through wood and by Dr. Schneider on polymerimpregnated wood. The pioneering work by Dr. Sebastian led to better understanding of pit aspiration in spruce (Picea spp.)

\footnotetext{
${ }^{1}$ Wood Science and Technology Centre, Faculty of Forestry and Environmental Management, University of New Brunswick, Hugh John Flemming Forestry Centre, 1350 Regent Street, Fredericton, New Brunswick E3B 2G6.

${ }^{2}$ Director, Professor. Corresponding author. E-mail: yhc@unb.ca

${ }^{3}$ Research Associate

${ }^{4}$ Research Scientist
} 
and "plugs" in sugar maple (Acer saccharum Marsh.), which explained their resistance to fluid flow. Dr. Schneider's research programme on polymer-impregnated wood spanned over 40 years. He is still actively pursuing research in that area. Commercial facilities have been established in Europe to produce products using technologies developed by Dr. Schneider. In 1986, the complement of wood science faculty was increased by one with the hiring of Dr. Ian Smith, a renowned expert in wood engineering. By that time, the Wood Science Option was no longer available. Dr. Sebastian retired 1989 and that faculty position was subsequently filled in 1993 by the first author.

Before the late 1980s the wood products industry in Atlantic Canada was primarily a producer of commodity lumber products, with the majority of production being spruce-pine-fir lumber exported to Europe. Recognizing the need to diversify its product base and add value to primary products, the wood products industry in Atlantic Canada started accelerating its activities in producing value-added wood products in the late 1980s. The term "value-added wood products" became a buzz word in the wood products industry, and business development and natural resources departments of provincial and federal governments. Various studies have been commissioned by government departments to review the status of the primary and secondary wood sectors and identify suitable product opportunities for local companies. Establishment of the Atlantic Canada Opportunities Agency (ACOA) by the federal government in 1987 has provided some welcome business assistance, in addition to that already offered by provincial government departments, to wood products companies wishing to undertake business expansion, improve production efficiency and invest and adopt new technologies. A New Brunswick provincial government task force in the mid-1980s identified the need to establish a technical centre to support the innovation needs of the wood products industry in the region. In 1988, the Wood Science and Technology Centre (WSTC) was established at UNB, with funding provided by UNB, ACOA and the New Brunswick Government. Administratively, WSTC operates under the auspices of the Faculty of Forestry and Environmental Management with advice and direction provided by an industrial advisory board. More discussion on the activities of WSTC and the role it plays in linking the academic programs and industry will be discussed later in this paper.

In the mid-1990s the Faculty of Forestry and Environmental Management undertook a major review of its two undergraduate programs, forest resources and forest engineering. This review reduced the number of wood-related courses from two to one. The Construction Wood Products course was removed from the curriculum, and only the Wood Technology course remained. Ironically this change came at a time when demand for university graduates with a strong background in wood science and wood products had increased. As stated above, the wood products industry in Atlantic Canada, and indeed the whole of Canada, started to focus more on value-added products. An end result of this was that the industry became more technology-conscious, necessitating the need to have in-mill professionals who possess appropriate technical skills to solve process problems, develop new niche products, solve performance problems of products in service, and introduce changes to manufacturing processes to reduce costs. With this in mind and in order to allow students in the undergraduate programmes to acquire specialization in wood products, the Faculty introduced a Minor in Wood Products. A more recent curriculum change in the BSc Forest Engineering programme has resulted in extension of the focus of the core program from "forestry activities up to the mill gate" to the "manufacturing end" of the forest industry.

\section{Wood Products Innovation Needs for Atlantic Canada}

Forests in Atlantic Canada have a higher hardwood to softwood tree ratio $(27 \% / 73 \%)$ than the Canadian average (20\%/80\%). Therefore, in comparison with most other provinces, Atlantic industry has more opportunities for product diversity and higher-value products as hardwood products tend to command a higher product value per unit volume than softwood products. The major softwood species are the spruces and balsam fir (Abies balsamea [L.] Mill.), which account for almost all spruce-pine-fir dimension lumber production from Atlantic Canada. Other commercially important softwood species are jack pine (Pinus banksiana Lamb.), red pine (Pinus resinosa Ait.), white pine (Pinus strobus L.), eastern white cedar (Thuja occidentalis L.), tamarack (Larix laricina [Du Roi] K. Koch) and eastern hemlock (Tsuga canadensis [L.] Carr.), but these exist in relatively small quantity. With the exception of jack pine, these relatively minor species are primarily used in manufacturing non-commodity products, such as shingles, flooring, moulding, log homes, utility poles and siding. Major hardwood species include sugar or hard maple, and red (Acer rubrum L.) maple, and yellow (Betula alleghaniensis Britt.) and white (Betula papyrifera Marsh.) birch, and aspens (Populus grandidentata Michx. and Populus tremuloides Michx.). Major value-added products from these species are flooring, cabinetry components and moulding.

As stated, before the mid-1990s wood product production in Atlantic Canada was heavily dominated by commodity lumber products. The authors have estimated that in 2005, the proportion of primary lumber product in the total shipment value has dropped to about $36 \%$ for the province of New Brunswick. Table 1 shows the results of an estimate of the shipment values for various products from New Brunswick producers based on information collected from Statistics Canada and local trade association. Although the authors did not have any specific shipment data for mid-1990s, it was certain that the corresponding proportion of primary lumber products at that time was significantly higher than 36\%. Significant growth was observed in engineered wood products, panel products, manufactured housing, remanufactured components and cabinetry/millwork between the mid-1990s and 2005. Despite this growth in secondary, value-added wood products, the general thinking within the wood industry and government departments is that further growth is desired so that the wood products industry is less vulnerable to fluctuation in commodity prices and able to diversify its markets. To achieve this goal, there is a need for the industry to either adopt/adapt proven technologies or develop new technologies/product concepts that can be commercialized by the industry. A review of some of the plausible technologies that may be suited for local industry is presented below. The discussion is separated into six different categories: 1. Technologies that produce new building components and systems; 2. Technologies that produce reconstituted wood products; 3 . Technologies that modify wood properties; 
Table 1. Major forest products produced by New Brunswick companies and primary species used for each ${ }^{a}$

\begin{tabular}{lccll}
\hline Product & Value $(\mathbf{\$})$ & Percent & Major species & Category \\
\hline Manufactured housing & 130 & 8 & Spruce, jack pine, fir & Structural \\
Softwood lumber & 600 & 36 & Spruce, jack pine, fir & Structural \\
Wood-based panels & 180 & 11 & Spruce, aspen, mill residues & Non-structural \\
Engineered wood products & 180 & 11 & Spruce & Structural \\
Post \& beam, log homes & 10 & 1 & Cedar, white pine, spruce & Non-structural \\
Shingles & 20 & 1 & Cedar & Non-structural \\
Boxes, pellets, etc. & 50 & 3 & HW & Non-structural \\
Cabinet, moulding, millwork & 170 & 10 & Dense HW , white/red pine & Appearance \\
Reman components & 190 & 11 & Dense HW, white/red pine & Appearance \\
Wood furniture & 70 & 4 & Dense HW & Appearance \\
Other specialty products & 70 & 4 & - & Unknown \\
Total wood & $\mathbf{1 6 7 0}$ & $\mathbf{1 0 0}$ & - & - \\
Total pulp and paper & $\mathbf{1 3 2 8}$ & - & HW and SW & P \& P residues \\
\hline
\end{tabular}

aSource: Wood Products Group (2003) and Industry Canada (n.d.)

${ }^{b}$ Sugar maple, yellow birch, beech (Fagus americana Ehrh.), oak (Quercus spp.).

4. Environmentally friendly technologies that enhance natural durability of wood; 5 . Technologies that scan wood products to improve product recovery and quality; and 6. Technologies that extract chemicals from wood.

Technologies that produce new building components and systems Low-rise building construction is the major end use of wood products. Until the early 1990s, framing members in North American low-rise buildings consisted primarily of softwood dimension lumber. In recent years, large dimension lumber members $(2 \times 8$ and up) have been replaced by engineered wood products such as wood I-joists and open-web trusses. New Brunswick is home to two major producers of wood Ijoists. WSTC was involved at the outset in assisting these two mills with their start-up process and subsequently performed qualification tests and R\&D for these two mills. A number of research projects on wood I-joists were conducted by WSTC with support from the Natural Resources Canada's Value to Wood program (Chui and Delahunty 2005, Chui et al. 2005, Pirzada and Chui 2007, Chui et al. 2007). The production of these engineered wood products requires use of high-strength lumber. While the wood fibre quality of local softwood species is good from a machining perspective, the strength properties of lumber are not high enough to allow the final engineered wood joists to be competitive. As a result, both New Brunswick wood I-joist producers "import" high-density dimension lumber from sources outside of Atlantic Canada. The region currently does not have any manufacturers of another category of engineered wood products known as structural composite lumber (SCL). SCL, which could provide an alternative to strong dimension lumber, includes products such as laminated veneer lumber and oriented strand lumber.

Given these issues, it is expected that production of engineered wood products in Atlantic Canada has reached saturation and its growth will be limited. With this in mind, it is the authors' opinion that future growth, and therefore R\&D needs, in the building product sector in Atlantic Canada will likely be in building systems rather than individual building components. Future R\&D efforts should be directed towards developing innovative building systems comprising a number of components, each of which plays a specific role in ensuring that the system meets building code requirements. Atlantic Canada already has a strong prefabricated building industry, which has experienced exceptional growth in the last few years. A major reason for this growth is the lack of skilled labour in the construction industry, causing builders and consumers to rely more on factory-built components, than stick-building on site. So far, the factory-built components and systems in Atlantic Canada have been limited to traditional lumber-to-sheathing construction that replicates the accepted details in North American building codes.

One technical issue facing the prefabricated building industry is damage induced in sheathing panels such as drywall and oriented strand board (OSB) during transportation. This was a subject of research in another Value to Wood project at UNB (Smith et al. 2007). Other R\&D needs that are of specific interest to Atlantic Canadian manufacturers are:

- Development of efficient connection systems that can be applied to connect prefabricated building systems on site, and maintain the building envelope integrity, energy and structural sufficiency of the whole building.

- Integration of innovative building components that can provide enhanced performance, such as structural insulated panel (SIP), into prefabricated systems.

Interested readers can consult a detailed technology road map prepared by the Manufactured Housing Research Alliance in collaboration with US Department of Housing and Urban Development for more information on future R\&D needs of this sector (Manufactured Housing Research Alliance 2003).

\section{Technologies that produce reconstituted wood products}

Reconstituted wood products are a family of wood composite products that typically involve first breaking down logs into smaller pieces (e.g., veneers, strands, particles, flakes, etc.) and bonding these pieces using an adhesive to make the final product. The most common reconstituted wood-based products are panel products, which include plywood, OSB, particleboard, medium-density fibreboard, and the SCL family of products.

Atlantic Canada is home to a number of panel product manufacturers, but there are no producers of SCL products in 
the region. The two major issues that are currently causing concerns to this sector are shortage of available raw materials and restriction by some local authorities on use of products containing formaldehyde-based adhesives. The second issue is because the majority of the adhesives currently used by panel product manufacturers contain formaldehyde, which has been classified as a carcinogenic agent. A less urgent issue is to reduce the density of the products. With the exception of plywood, all panel products have density that is substantially higher than the wood material that is used in making the panel because the material experiences densification during manufacturing. This increases handling effort and transportation costs.

To address the fibre shortage problem, collaborative research is being conducted at WSTC and FPInnovations Forintek Division to develop appropriate processes to include agricultural fibres in particleboard production. Both loose and mat-form agricultural fibres are being investigated. The rationale of using mat-form fibres is that they may provide a strength-reinforcement effect leading to reduced panel density for the same performance level. The mat reinforcement may also provide an opportunity for the industry to produce high-performance panels with, for example, higher fastenerholding capacity and bending strength.

There is currently a number of potential alternatives to formaldehyde-based adhesives, including soy bean, lignin, furfuryl alcohol and pyrolysis oil. A patent entitled "Furfuryl alcohol-lignin wood adhesive, fibre reinforced material matrix compound and porous material surface reinforcing compound" was recently awarded to retired UNB professor Dr. Marc Schneider and J.G. Phillips (U.S. Patent \# 6,747,076). Furfuryl alcohol-lignin was the main adhesive in the matrix. Further characterization of the adhesive is currently a subject of a PhD thesis project at UNB (Leger et al. 2007). Pyrolysis oil (PO), obtained from thermal decomposition of softwood barks, has been applied in oriented strandboard (OSB) where up to $45 \%$ (by weight) of phenol was replaced in the phenolformaldehyde (PF) resin formulation (Chan et al. 2002). These resins (PF-PO) with an additive were successfully incorporated as a binder in OSB, which possessed significantly improved mould growth resistance and had mechanical properties comparable with commercial OSB panels.

Resin is a major cost item in manufacturing of wood composites and other glued wood products. One solution to this problem is to reduce or eliminate the need of a binder in wood composite manufacturing. Research conducted overseas (Angèls et al. 1999, Widyorini et al. 2005, Okuda and Sato 2006) has demonstrated that binderless boards from softwood and agri-based fibres can be produced with mechanical properties comparable to those bonded with synthetic resins. The process of making binderless boards generally involves thermo-mechanical treatment of fibres, which causes auto-hydrolysis of their main chemical components: hydrolysis of hemicelluloses, slight depolymerization of celluloses and melting and progressive depolymerization of lignin. This process makes the main fibre chemical components more accessible for the polymerization reaction during the hot pressing process of composite manufacture, and essentially makes use of the natural binder inside wood. The authors feel that although commercial implementation of binderless board technologies is still years or even decades away, it will one day become a reality.

\section{Technologies that modify wood properties}

Wood is a natural material with little opportunity for humans to control its formation and, therefore, its properties. Some of wood's less desirable characteristics, such as dimensional movement after adsorption or desorption of water and susceptibility to attack by micro-organisms under certain conditions, are limiting its use. Wood that has endured a treatment during which its cellular structure and/or cell wall components have been modified physically or chemically could have better properties, such as durability, dimensional stability and strength, than untreated wood of the same origin. The most common wood modification processes that have been applied commercially to varying degrees of success are polymer impregnation, thermal modification and mechanical densification (Homan and Jorissen 2004).

Polymer impregnation is a process by which wood cell walls are penetrated by low-molecular-weight precursors that are polymerized, usually facilitated by heating, inside the wood cellular structure (Rowell 2006). Basically, there are two modifying approaches, modification of the lumen (cellular level) and modification of the cell wall material (molecular level). A promising polymer-modified wood-furfurylated wood-has been developed by retired UNB professor Dr. Schneider (Schneider 2007). In the furfurylation process, furfuryl alcohol derived from agricultural waste, such as corn cobs or sugar cane residues, impregnates wood using a vacuum-pressure treating process and cures in a conventional kiln. Furfurylated wood is non-toxic, shows good dimensional stability and high bio-deterioration resistance, and can be used as flooring, furniture and siding.

Solid wood can be heat-treated at high temperatures to improve durability and dimensional stability. The principle of this technology is that heat alters the chemical composition (primarily hemicellulose and lignin) of wood and hence its physical properties. This process is generally known as thermal modification, which is an environmentally friendly process since no chemicals are added and the process requires only heat and steam. Thermal modification technology, basically, heats wood to a temperature close to or above $200^{\circ} \mathrm{C}$ for a period of time ranging from a few hours to a few days in an atmosphere with low oxygen level or a non-combustible gas such as nitrogen. By this treatment some mechanical properties are reduced, while dimensional stability and biological durability of wood is improved. However, this technology has not been widely adopted commercially mainly because the processes are complicated in large-scale production due to the high temperature used and the initial capital investment. Currently, there are at least three commercial facilities in eastern Canada that can produce thermally modified wood. In general, the thermally modified wood products have found use in non-engineering applications, such as siding, decking, and flooring.

Mechanical densification of wood is a technology whereby wood is compressed to reduce the void space in cell lumen. This process is often applied with heat and added moisture or steam to produce a higher-density product exhibiting better mechanical performances. In terms of degree of densification, this technology has two approaches-surface densification and full densification. Surface densification simply compresses the surface layer (about 3-5 $\mathrm{mm}$ ) of wood to improve the surface hardness and abrasive resistance, and minimize the loss of wood volume caused by densification. The surfacedensified products can be used for flooring, stair treads and 
table tops. The full densification process densifies wood in the thickness direction to a certain level to increase the modulus of elasticity, modulus of rupture, nail withdrawal resistance and hardness. However, this process causes a large loss of wood volume. The fully densified products can be used for indoor structural applications such as beams and posts. Overall, mechanical densification technology is very promising to turn low-density under-utilized wood into higher-value products. However, a major drawback of densified wood is its relatively poor dimensional stability when the product is subjected to a humid environment (Gong and Lamason 2007). Current research at WSTC is intended to address the dimensional stability issue (Lamason and Gong 2007).

Each of the above wood modification techniques has strengths and weaknesses with respect to specific applications. It is possible that the weakness of one technique can be addressed by the strength of another. Therefore, by combining these techniques, modified wood can be "engineered" to meet the performance requirements of not only any wood but non-wood products, thereby allowing the wood industry to develop new high-value product opportunities.

\section{Environmentally friendly technologies that enhance natural durability of wood}

Because wood is such an ubiquitous organic source of carbon, rich in nutrients that are readily available for microbial decay, and given the ubiquitous nature of micro-organisms, particularly the numerous wood-inhabiting fungi (white-rotting fungi, brown-rotting fungi, soft-rotting fungi, sapstaining fungi, moulds, and other opportunistic fungi), there is ample opportunity for all wood sources to be exposed to these biological agents of decay or deterioration. The only exception would be to keep the source of nutrients within a sterile environment. Of course, there are exceptions to this scenario that have been recorded where wood has been preserved under very favourable conditions. It is well known, for example, that wood in Japanese temples is still sound having been maintained under certain conditions for hundreds of years (http://www.cwc.ca/designwithwood/durability/wood+heritage/), and some wood is found preserved under the anaerobic, acidic condition of bogs (Bjordal and Nilsson 2001). The former is an example of good housekeeping, while the latter is an example of wood being preserved by a natural system. These are rare cases, however, and we are still left with a challenging problem of finding processes to prolong the service life of wood if we are to maximize the utility of this valuable resource that is shrinking in the industrial world.

The utility of prolonging the durability of wood by preservation has long been realized. The chemical preservation of wood has well served its purpose since the development of some of these quite effective wood preservatives in the 19th and 20th centuries. Recently, concerns over the impact of some of the traditional wood preservatives have seen regulations implemented to eliminate their usage in certain applications (PMRA 2004).

There seems to be a genuine need at present for a new generation of wood preservatives or a way to increase the durability of wood without the need for chemical treatment, given that the more traditional chemical treatments have gone by the wayside or are being phased out because of toxicity concerns in humans and other life forms, as well as their general impact on the environment. So far, it appears that little progress has been made to make wood more durable. One of the alternative approaches that have been researched is biological controls, whereby biological agents are used to inhibit the growth of other biological agents that cause wood deterioration. Much of this focus has been on developing sapstain control agents (Seifert et al. 1993, PMRA 2004, Morin et al. 2006). Some problems associated with sapstain fungi are that they cause discoloration of the sapwood, devalue the product, and can cause problems in applying coatings such as paints and varnishes. Staining can slightly decrease the strength properties of lumber, and sapstain fungi are themselves an extra nutrient source for secondary microbial colonization of the wood. Many sapstain fungi discolour wood because of pigmentation in their cell walls and spores. One method to control sapstain fungi is to grow another similar non-pigmented (also referred to as albino) fungus in its place (Morin et al. 2006). This is quite effective at preventing some other fungi from occupying, or growing into the same space within the wood, and takes advantage of a phenomenon referred to as "somatic incompatibility" in fungi. Another method uses growth of moulds to prevent growth of sapstain fungi, which takes advantage of inhibitory antifungal metabolites that are produced by the mould (Seifert et al. 1993). Pre-colonization of the wood with moulds has also been tested to control wood decay fungi (Highley et al. 1996).

Another biological control method that we have begun investigating at WSTC, led by UNB Professor Emeritus Dr. Norm Whitney involves use of non-decay-causing fungi that are not typical moulds or sapstain fungi found in wood, referred to as endophytic fungi. Endophytic fungi by definition are non-symptomatic fungi that live within the tissues of plants. Not much is known of such fungi that live within the woody stems of trees. However, research conducted at our facility strongly suggests that they may be inhibitory towards decay-causing fungi. We have isolated non-decay fungi from both wood in service and from living trees. The idea would involve inoculating seeds or seedlings with endophytic fungi antagonistic towards sapstain and decay fungi. As the tree grows and is ultimately harvested and processed into wood products, the final products would then have intrinsic resistance against sapstain or decay attack. Earlier research at UNB involving endophytic fungi isolated from within living conifer needles, has shown signs of success in control of spruce budworm (Choristoneura fumiferana (Clem.)). Currently, there is ongoing research focused on transplanting such fungi into seedlings to protect them against insect attack (Miller et al. 2007, Sumarah et al. 2008). We think that some endophytic fungi found within woody stems of trees, and/or the compounds they produce, may have great potential in providing wood with improved natural durability. More basic research and much development work is still required before it can be implemented. We feel that in the long term this technology may well prove to be the most effective and environmentally friendly means of improving natural durability of wood.

As was alluded to above, another alternative method of improving wood durability is through thermal modification. Thermal treatment alters the chemistry of wood cell wall components, thereby removing the source of nutrients to decay-causing fungi (Kamdem et al. 2002, Weiland and Guyonnet 2003.). The process can be applied at varying degrees of severity in terms of the treatment schedule, depending on the objective of the treatment that can range from improving 
dimensional stability, changing surface colour to complete decay resistance. To achieve a level of durability that is comparable with performance provided by traditional wood preservatives, the most severe treatment schedule is generally required leading to a significant reduction in some mechanical properties (Bekhta and Niemz 2003). The treated product often is dark and presents an unpleasant odour (Sundqvist 2004). The former may be an issue for certain applications where appearance of a product affects consumer choice. The strong odour associated with thermally modified wood is obviously related to changes in chemistry of wood. It is yet unclear regarding the impact of the changed cell wall chemicals of thermally modified wood on human health, but it is certainly an area that needs to be clarified if the product is to be accepted by consumers.

\section{Technologies that scan wood products to improve product recovery and quality}

Increasing raw material costs and declining wood quality has prompted the wood industry to adopt scanning technologies that allow more efficient sorting of raw material or finished products. Better sorting generally leads to more efficient use of raw material, improved recovery of high-grade material, improved quality of the final products, or a combination of these benefits.

Major improvements in scanning equipment, both in terms of processing speed and accuracy of measurements, have been achieved in the past two decades due in part to rapid advances made in electronics and image-processing technologies. The scanning and optimizing equipment currently found in the sawmilling industry in eastern Canada is among the most advanced in the world. Curve and shape sawing systems, and edging/trimming optimizers are commonly found in dimension lumber mills in eastern Canada. The industry was essentially forced to adopt advanced scanning systems in order to stay competitive because of declining sawlog quality and size in eastern Canada. A study conducted by FPInnovations - Forintek Division for eastern Canadian sawmills has revealed that the lumber recovery factor of these sawmills increased by about $40 \%$ in the last three decades while at the same time the average volume per sawlog decreased by about 30\% (Levesque 2002).

The scanning systems currently used by the sawmilling industry basically measure the geometry and dimensions of processed pieces using laser beams and sensors. Grading and sorting of lumber, which is based on examining surface defect types and sizes, is still largely performed by humans. This has begun to change with incorporation of other techniques in scanning systems that allow surface defects such as knots, slope of grain, splits, bark pockets and rot to be detected.

Currently, these defect-detection scanning systems are used in value-added wood products manufacturing facilities to remove defects during the manufacturing process. In these new systems, defect detection is achieved by using one of the three wavelength bands: X-ray, optical or microwave. Optical systems are often able to sort material according to colour, which for some appearance products, is an important feature. Commercial optical systems are either laser-based, such as the Cell Scan (http://www.barrmullin.com/cellscan.htm), or camera-based such as WoodEye (http://www.woodeyeinc.com/) and ChopScan (http://www.lucidyne.com/chopscan.asp).
Microwave and X-ray machines operate by measuring the density of a material. This is possible because surface defects of wood often either have a higher density (e.g., knots) or lower density (e.g., decay, bark, split) than clear wood. Microwave-based machines are primarily used for grading wood for structural applications. These include the SpeedGrader and Finnograder (Leicester 2004). Commercial machines incorporating X-ray wavelengths include X-Scan (http://www.luxscan.lu/mmp/online/website/content/products/63/index_EN.html) and Golden Eye (http://www. microtec.eu/valueshop/microtec.asp?GrpID=C:147645).

The commercial machines mentioned above are capable of operating in excess of $300 \mathrm{~m} / \mathrm{min}$. The current X-ray scanning system provides only spectral measurements, and as a result these systems only detect surface features. As the technologies to detect surface features of boards mature and allow optimization of processed boards to be achieved in terms of product value, it is expected that the wood industry will turn to the next generation of scanning systems that allow internal features of logs to be detected before conversion, thereby providing a means to optimize the sawing pattern of a log to maximize final product value. It is expected that the next generation of X-ray machines will provide full imaging known as $\mathrm{X}$-ray computing tomography (CT). A CT scanner sends an $\mathrm{X}$-ray beam of high electromagnetic energy towards an object. Some of the energy is then absorbed and other energy is transmitted. The transmitted electromagnetic energy is measured by detectors, which provide images of the object's internal density. This technique has been used for a long time in the medical field in detecting internal abnormal features. A number of exploratory studies have been conducted to assess the feasibility of using CT scanners to detect internal log features (McMillin 1982, Hou et al. 2005). However, robust data processing techniques are not yet available to enable automatic identification of types of internal features ( $\mathrm{Li}$ et al. 1996). These topics are the subject of $\mathrm{PhD}$ thesis research at UNB in conjunction with FPInnovations - Forintek Division (Wei et al. 2008).

\section{Technologies that extract chemicals from wood fibres}

All the technologies discussed above are related to either modifying processes to improve traditional products or using a different process to produce a substitute product. The current precarious situation of the forest industry has prompted industry to identify non-traditional products from wood fibres. Biorefinery has been touted as a process that can lead to a wide range of non-traditional, chemical-based products that can be produced from lignocellulosic fibres, including wood. A biorefinery is a facility that integrates biomass conversion processes and equipment to potentially produce fuels, power and chemicals from biomass. The biorefinery concept is analogous to petroleum refineries, which produce multiple fuels and chemical products from petroleum. Petroleum provides fuel and base materials such as plastics that are made into many consumer goods. However, this resource is not renewable and is expected to be depleted at some point in the not-too-distant future. Biorefinery offers the process to produce substitute fuel and raw materials for consumer products from a renewable source. Much like the pulping process, biorefinery breaks down wood fibres into its three major chemical constituents: lignin, hemicellulose and cellulose. 
These chemical constituents can be further processed into other high-value products, as illustrated in Fig. 1. Because there are many similarities between the traditional pulping and biorefinery process, biorefinery can be set up by converting idle pulp and paper mills, thereby reducing the need for initial capital investment.

of evaluation and testing of wood products to be acceptable to authorities in Canada and export markets, there was a need for WSTC to acquire the status of an accredited laboratory. WSTC has been an accredited laboratory by the Standards Council of Canada, first under the ISO 9001 "Quality management systems - requirements" and more recently ISO17025

"Competence of Testing and Calibration Laboratory." WSTC is believed to be the first university wood research laboratory in North America to acquire the accredited laboratory status. This status is important from two aspects. First, this allows WSTC to generate revenue to support its operations, conduct inhouse research and development projects and purchase equipment. Second, it provides credibility to its research activities.

In addition to conducting research and testing, WSTC also undertakes a technology transfer program coordinated by a dedicated technology transfer professional. Support to the technology transfer program is provided by faculty members, WSTC scientists and external experts

Role Played by WSTC in Assisting the Atlantic Canadian Wood Products Industry with its Technology Needs

The Wood Science and Technology Centre was established in 1988 , with the objective of providing a bridge between the University and the wood industry in the region. One of the main goals of WSTC was to undertake research, through graduate student and faculty research, on new products and processes, and transfer the technologies to the wood industry. Initial start-up funding from government agencies allowed WSTC to acquire some research equipment and staff the Centre with a wood-processing specialist and a technician. Since its inception, the position of WSTC Director has been held by a faculty member from the Faculty of Forestry and Environmental Management.

It was intended that WSTC would become a technical centre that individual companies, trade associations and government departments would contact to seek technical assistance. To ensure that its activities are relevant and industry-oriented, the management of WSTC receives advice from an industrial advisory board. It soon became clear that in order to respond to the technical needs of the wood industry in a timely manner, it cannot rely solely on faculty members because their prime duty is to perform their academic responsibilities. Subsequently, through years of evolvement, a scientific team comprising members with a broad range of expertise has been built at WSTC. With its research facility and scientific staff, WSTC was often requested to evaluate and test wood products to meet building code and pest control requirements both in Canada and in export markets. For the results from the private sector and other research organizations such as FPInnovations. Technology transfer covers activities such as technical evaluation of equipment, preliminary technical evaluation of new product concepts, in-plant evaluation of manufacturing process efficiency and problems, and identification of sources of performance problems of products in service. Under the technology transfer program, WSTC assists on average between 30 and 50 companies per year.

In parallel with the industry-oriented activities, there is academic research undertaken by graduate and undergraduate students under the supervision of WSTC scientists. Over the years some of the graduate and undergraduate students who undertook research work at WSTC found employment either with WSTC as research scientists or with WSTC clients working in various technical and sales capacities.

\section{Concluding Remarks}

It is well recognized that the wood products industry in Atlantic Canada is facing some major challenges in the next few years, and is in need of some restructuring and long-term strategic changes in terms of the types of products that should be produced, given the characteristics of resources, proximity to certain export markets and technical support infrastructure. The industry, government departments and research community should shift from the traditional thinking that wood products industry is a resource-based industry to a manufacturing industry. This shift in thinking will lead to more effort put into development of new products, integration of wood with other materials, and development of prod- 
ucts that are substitutes of products made with other materials such as plastics and metals. This is the time when more highly qualified workers and technical assistance are required. It is believed that the Faculty of Forestry and Environmental Management, and in particular the Wood Science and Technology Centre, will continue to play a role in helping the wood products industry in addressing these challenges.

\section{Acknowledgements}

The authors thank Dr. Marc Schneider for providing information on the history of wood science instruction and research at the Faculty of Forestry and Environmental Management, UNB.

\section{References}

Angèls, M.N., J. Reguant, D. Montané, F. Ferrando, X. Farriol and J. Salvadó. 1999. Binderless composites from pretreated residual softwood. J. Appl. Polymer Sci. 73: 2485-2491.

Bekhta, P. and P. Niemz. 2003. Effect of high temperature in the change in color, dimensional stability and mechanical properties of spruce wood. Holzforschung 57: 539-546.

Bjordal, C.G. and T. Nilsson. 2001. Waterlogged archaeological wood - a substrate for white rot fungi during drainage of wetlands. Int. Biodeterioration \& Biodegradation 50: 17-23.

Chan, F., B. Riedl, X.-M. Wang, X. Lu, H. Pakdel, D.Q. Yang and C. Roy. 2002. Pyrocycling process for the conversion of softwood bark to pyrolysis oil used in the formulation of wood adhesives and wood preservatives for OSB. Poster, 56th Annual Meeting of the Forest Products Society, June 23-26. Madison, WI.

Chui, Y.H. and S. Delahunty. 2005. Engineered wood products made from red maple. Final report submitted to Natural Resources Canada for project UNB6, Wood Science and Technology Centre, University of New Brunswick, Fredericton, NB.

Chui, Y.H., G. Pirzada and S. Lai. 2005. Enhancing shear and bearing strength of wood I-joists. Final report submitted to Natural Resources Canada for project UNB3, Wood Science and Technology Centre, University of New Brunswick, Fredericton, NB.

Chui, Y.H., Q. Wang and G. Pirzada. 2007. Influence of OSB web stock properties on performance of wood I-joists. Final report submitted to Natural Resources Canada for project UNB76, Wood Science and Technology Centre, University of New Brunswick, Fredericton, NB.

Gong, M. and C. Lamason. 2007. Improvement of surface properties of low density wood: Mechanical modification with heat treatment. Final report submitted to Natural Resources Canada for project UNB57, Wood Science and Technology Centre, University of New Brunswick, Fredericton, N.B.

Highley, T.L., H.S.A. Padmanabha and C.R. Howell. 1996. Antagonistic properties of Gliocladium virens against wood attacking fungi. The International Research Group on Wood Protection. Section 1. Biology. IRG/WP 96-10162. Stockholm, Sweden. 9 p.

Homan, W.J. and A.J.M. Jorissen. 2004. Wood modification developments. Heron 49 (4): 361-386.

Hou, Z.Q., S.Y. Zhang and L.J. Hu. 2005. Determining wood density and its 3-D distribution in a log using computed tomography scanning technique. Proceedings of the $14^{\text {th }}$ International Symposium on Non-destructive Testing of Wood, Shaker Verlag, Germany. pp. 427-433.

Industry Canada. (n.d.). Trade Data Online (TDO) [online]. Available at http://www.ic.gc.ca/epic/site/tdo-dcd.nsf/en/Home.

Kamdem, D.P., A. Pizzi and A. Jermannaud. 2002. Durability of heat-treated wood. Holz als Roh-und Werkstoff 60: 1-6.

Lamason, C. and M. Gong. 2007. Optimization of pressing parameters for mechanically surface-densified aspen. For. Prod. J. 57(10): 64-68. Leger, C., F. Chan and M. H. Schneider. 2007. Examining the furfuryl-alcohol lignin reaction with differential scanning calorimetry.
Poster, the Forest Products Society - Eastern Canadian Section Meeting, Pembroke, Ontario, May 16-17, 2007.

Leicester, R.H. 2004. Grading for structural timber. Prog. in Struct. Eng. and Mater. 6(2): 69-78.

Levesque, Y. 2002. Evolution of sawmilling technologies of eastern Canada. Presentation S1003 at the 2002 Smallwood Conference, FPInnovations - Forintek Division, St-Foy, QC.

Li, P., J. He, L. Abbott and D.L. Schmoldt. 1996. Labeling defects in CT images of hardwood logs with species-dependent and speciesindependent classifiers. Proceedings of the IAPR TC-8 Workshop on Machine Perception Applications, Technical University Graz, Austria. IEEE and ISPRS. pp.113-126.

Manufactured Housing Research Alliance. 2003. Technology road mapping for manufactured housing. Report prepared in Collaboration with US Department of Housing and Urban Development, Manufactured Housing Research Alliance, New York, NY.

McMillin, C.W. 1982. Applications of automatic image analysis to wood science. Wood Sci. 14(3): 97-105.

Miller, J.D., M.W. Sumarah and G.W. Adams. 2007. Effect of a rugulosin-producing endophyte in Picea glauca on Choristoneura fumiferana. J. Chem. Ecol. LLC 2007 10.1007/s10886-007-9412-0. Springer Science+Business Media. 8 p.

Morin, C., P. Tanguay, C. Breuil, D.-Q. Yang and L. Bernier. 2006. Bioprotection of spruce logs against sapstain using an albino strain of Ceratocystis resinifera. Phytopathology 96: 526-533.

Okuda, N. and M. Sato. 2006. Water resistance properties of kenaf core binderless boards. J. Wood Sci. 52: 422-428.

Pest Management Regulatory Agency (PMRA). Ophiostoma piliferum Strain D97. Sylanex Technical (TGAI). Sylanex (EP). Regulatory Note: REG2004-05. Health Canada. Ottawa, ON. 26 p. Available at http://www.pmra-arla.gc.ca/english/pdf/reg/reg2004-05-e.pdf

Pirzada, G. and Y.H. Chui. 2007. Optimized design of wood I-joists. Final report submitted to Natural Resources Canada for project UNB61, Wood Science and Technology Centre, University of New Brunswick, Fredericton, NB.

Rowell, R. M. 2006. Chemical modification of wood: A short review. Wood Mater. Sci. \& Eng. 1: 29-33.

Schneider, M.H. 2007. Furfurylated wood. Presentation at the 28th Annual Meeting of the Canadian Wood Preservation Association, Quebec City, Oct. 16-17.

Seifert, K.A., B. Bilmer and M.C. Mes-Hartree. 1993. Method for protection of lumber against sapstain. Publication No. WO/1993/ 001923. World Intellectual Property Organization.

Smith, I., A. Asiz and G. Gupta. 2007. High performance modular wood construction systems. Final report submitted to Natural Resources Canada for project UNB5, Wood Science and Technology Centre, University of New Brunswick, Fredericton, NB.

Sumarah, M.W., G.W. Adams, J. Berghout, G.J. Slack, A.M. Wilson and J.D. Miller. 2008. Spread and persistence of a rugulosin-producing endophyte in Picea glauca seedlings. Mycol. Res. 112(Pt 6): 731-736.

Sundqvist, B. 2004. Colour changes and acid formation in wood during heating. $\mathrm{PhD}$ Thesis. Lulea University of Technology, Skellefta, Sweden.

Wei, Q., B. Leblon, Y.H. Chui and S.Y. Zhang. 2008. Identification of selected wood characteristics from computed tomography images of sugar maple logs using maximum likelihood classifier and textural analysis. Holtzforschung 62(4):441-447.

Weiland, J. and R. Guyonnet. 2003. Study of chemical modifications and fungi degradation of thermally modified wood using DRIFT spectroscopy. Holz als Roh-und Werkstoff 61: 216-220.

Widyorini, R., T. Higashihara, J. Xu, T. Watanabe and S. Kawai. 2005. Self-bonding characteristics of binderless kenaf core composites. Wood Sci. Technol. 39: 651-662.

Wood Products Group. 2003. Value-added wood products and New Brunswick Crown Forest. Presentation to the New Brunswick Select Committee on Wood Supply, December 4, Fredericton, N.B. 